\title{
The population of Brazil, 1570-1700: a historiographical review
}

\author{
Angelo Alves Carrara[1]
}

\begin{abstract}
This article reviews the historiography of Brazil's population estimates for the period from 1570 until the beginning of the 18thcentury, with special attention to Contreiras Rodrigues, whose work became a benchmark for nearly all studies. The article also aims to compare the data with other available sources, such as tax sources, as well as to assess the validity of the proposed estimates.

Keywords: colonial Brazil; population; historiography.
\end{abstract}

\section{A população do Brasil, 1570-1700: uma revisão historiográfica}

\section{Resumo}

Este artigo passa em revista a historiografia relativa às estimativas de população do Brasil para o período de 1570 até o alvorecer do século XVIII, com especial atenção ao autor que se tornou a referência de quase todos os estudos, Contreiras Rodrigues. O trabalho também busca confrontar os dados com outras fontes disponíveis - como as fontes fiscais - , bem como aferir a validade das estimativas propostas.

Palavras-chave: Brasil Colônia; população; historiografia.

\section{La población de Brasil, 1570-1700: una revisión historiográfica}

\section{Resumen}

Este artículo revisa la historiografía sobre las estimaciones de población de Brasil para el período de 1570 hasta los albores del siglo 18, con especial atención al autor que se convirtió en la referencia de casi todos los estudios, Contreiras Rodrigues. El trabajo también busca comparar datos con otras fuentes disponibles - como las fuentes tributarias - , así como evaluar la validez de las estimaciones propuestas.

Palabras clave: Brasil Colonia; población; historiografía.

\section{La population du Brésil, 1570-1700: une révision historiographique}

\section{Résumé}

Cet article recapitule l'historiographie concernant l'estimations de la population du Brésil de 1570 jusquà l'aube du XVIIIe siècle, en étant particulièrement attentif à l'auteur qui est devenu référence dans les études, Contreiras Rodrigues. On cherche de comparer lês donnés avec d'autres sources par exemple, les sources fiscales -, et de valider les estimations proposées.

Mots-clés: Brésil colonial; population; historiographie. 
$\mathrm{T}$ he estimates of the population of Brazil for the 16th and 17th centuries that are now considered valid were based on data presented by Roberto Simonsen from analysis performed by Félix Contreiras Rodrigues. For 1690, however, Simonsen somewhat diverges from his source and presents an average of both figures proposed by Contreiras Rodrigues for $1660(184,000)$ and 1700 $(300,000)$, that is, 242,000 inhabitants. These are the figures included in the historical statistics of Brazil by the Brazilian Institute of Geography and Statistics and replicated widely. ${ }^{1}$ This study aims to review the calculation and the results proposed by Contreiras Rodrigues as well as to assess its validity.

The sources of Contreiras Rodrigues are as follows:

1. For 1570, the sources are Chapters 1-9 of Tratado da Terra do Brasil, written by Pero de Magalhães Gândavo. The author uses data from Gândavo, given in an article by Silvio Ferreira Rangel, published in Revista do Instituto Histórico e Geográfico Brasileiro (special volume, part 4). However, there is a slight difference in the figures for the captaincy of Porto Seguro: Contreiras presents a total of 200 (and not 220, as originally stated by Gândavo), which does not significantly alter the correct total of 3,440 neighbors; Contreiras assigns each hearth ("neighbor", in the original work) five persons, which constitutes a total of 17,200 residents of Portuguese origin; ${ }^{2}$

2. For 1585, the source is Anchieta, which he also reached indirectly. The method is the same adopted before: multiply by five the number of neighbors of Portuguese origin given by Anchieta $(5,595)$, adding that total to the total of African slaves $(13,000)$ and Christian Indians $(17,500)$, which totals

'Roberto Simonsen, História econômica do Brasil, 6 ed., São Paulo, Companhia Editora Nacional, 1969, p. 221; Félix Contreiras Rodrigues, Traços da economia social e politica do Brasil colonial, Rio de Janeiro, Ariel, 1935, p. 31-34; Instituto Brasileiro de Geografia e Estatística, Estatísticas históricas do Brasil, 2 ed., Rio de Janeiro, IBGE, 1990, p. 30. The 300,000 inhabitants' figure at the turn of the 17th to the 18th century, proposed by Contreiras Rodrigues, established itself over time in studies such as Maria Luiza Marcílio, "Évolution historique de La population brésilienne jusqu'en 1872", In: Committee for International Cooperation in National Research Demography, La population Du Brésil, Paris, Committee for International Cooperation in National Research Demography, 1974, p. 7-27 (p. 10: "the best estimates for the total population of Brazil in 1550, 1600, and 1660, drawn from a variety of sources, are still to be found in Félix Contreiras Rodrigues"); Idem, "The population of colonial Brazil", In: Leslie Bethell (ed.), The Cambridge History of Latin America, Cambridge, Cambridge University Press, 1984, p. 37-63 (Colonial Latin America, vol. 2); Maria Beatriz Nizza da Silva, "A população", In: Harold Johnson; Maria Beatriz Nizza da Silva (coords.), O império luso-brasileiro, 1500-1620, Lisboa, Estampa, 1992, p. 305-333; Clotilde Andrade Paiva; José Alberto Magno de Carvalho; Valéria da Motta Leite, "Demografia”, In: Instituto Brasileiro de Geografia e Estatística, Estatísticas históricas do Brasil, 2. ed., Rio de Janeiro, IBGE, 1990, p. 19-52. In turn, the figures reproduced by Simonsen (1969) and Marcílio (1984) were also recently recognized by Angus Maddison, The World Economy, vol. 1, Paris, OECD Publishing, 2006, p. 234-235.

2Regarding the use of the term "neighbor", Teresa Rodrigues notes that the concepts of resident, neighbor, and hearth are used in 16th century sources, "and we don't know its exact meaning and, a fortiori, their quantitative equivalence. And even less if there was a uniformity of criteria by the agents responsible for counting. Much has been said about the correct coefficient to estimate, based on these concepts, the total population. To João Alves Dias, this coefficient must be between 4 and 5 , which he obtained a result of several analyses of coeval documentation. In the 17th century, in addition to these concepts, those of souls, communicants, children under discretion age and children under communion age [which was between seven and eight years] were also used. The last two corresponded more clearly to age criteria, which enables a perception and estimation of the recruitable population in the country". Teresa Rodrigues, Portugal nos séculos XVI e XVII: vicissitudes da dinâmica demográfica, Porto, Centro de Estudos da População, Economia e Sociedade, 2004 (working paper - first version on the history of the Portuguese population in the 16th and 17th centuries - study conducted under project POCI/DEM/57987/2004 "História da População Portuguesa: das grandes permanências à conquista da modernidade, p. 16-17"). 
57,600 inhabitants throughout Brazil. The problem is that, for Pernambuco, there are 8,000 whites, corresponding to 1,000 neighbors; for Bahia, there are 8,000 African slaves and 4,000 Indians are also incongruent with the figures of Anchieta; for Ilhéus, Porto Seguro, Espírito Santo, and Rio de Janeiro, the total number of Portuguese people he reports is of 750 per captaincy. The reported numbers of 4,500 Indians for Espírito Santo and the 3,000 for Rio de Janeiro are consistent with Anchieta. Also, it is not clear on what basis Contreiras Rodrigues estimated 1,000 African slaves for the captaincy of São Vicente.

3. For 1600, Contreiras Rodrigues takes data from Rocha Pombo, who estimates 30,000 whites and 70,000 mixed-race people, blacks, and Indians; here, the source is highly questionable, whether for the complete absence of references or the fragility of the statements. Here is a quick example: on Espírito Santo, Rocha Pombo pointed out that "by the beginning of the 17th century, there were many sugar farms in that area" and that Vitória, "by 1600, had about 700 inhabitants". What different sources attest is that Espírito Santo, until 1629, had no more than eight sugar farms; ${ }^{3}$

4. For the population of the mid-17th century and "according to various sources", the author says - these are his own words - that there were 184,100 people, thus broken down: Maranhão and Grão-Pará (between whites and free Indians, slave Indians from Marajó): 40,000; Ceará: 100; Recife: 2,000 Portuguese people and 15,000 slaves; Olinda: 3,500 Portuguese people and 5,000 slaves; Salvador and Recôncavo: 10,000 Portuguese people and 30,000 slaves; Ilhéus and Espírito Santo: 1,000 Portuguese people; Rio and Guanabara: 3,500 Portuguese people; and São Vicente: 4,000 Portuguese people and 60,000 slaves. Of all these figures, the most surprising one is the number of 60,000 slaves in São Vicente. It seems very clear that the author has taken the figure from a passage by Rocha Pombo, describing the attack carried out on the Jesuit missions in the South in 1629: "in less than three years, over 60,000 slaves were sold to the captaincies". "That number alone would represent a third of the total population of Brazil at the time;

5. Finally,

as for the population in 1690, when the first discoveries of gold mines took place, or 30 years after the last demographic estimation, in the face of the famine that afflicted the old world, it is no exaggeration to add to the 184,000 inhabitants in $1660,100,000$ mixed-race and foreign people, which would, at that time in our history, account for a total of $284,000-300,000$ inhabitants. $^{5}$

The inevitable conclusion is that the figures of Contreiras Rodrigues for the 17 th century are not minimally acceptable. Well, the study of the demographics

${ }^{3} J o s e ́$ Francisco da Rocha Pombo, História do Brasil, vol. 2, Rio de Janeiro, W.M. Jackson, 1942, p. 56; the number of sugar farms is presented by Stuart B. Schwartz, Segredos internos, São Paulo, Companhia das Letras, 1988, p. 148.

4José Francisco da Rocha Pombo, op cit., p. 68-69.

${ }^{5}$ Félix Contreiras Rodrigues, Traços da economia social e política do Brasil colonial, Rio de Janeiro, Ariel, 1935, p. 34. 
of colonial Brazil in the 17th century must take into account three key variables: the Portuguese population, the sugar economy, responsible for almost all of the demand for African slaves, and the ability to incorporate Indians into the colonial society.

Regarding the Portuguese population, one has to agree with Teresa Rodrigues that, more than numbers, which are admittedly very difficult to use, "It is worth highlighting the trend lines of population growth". Although some figures are available, disagreements persist, given the impossibility of "safely asserting what is the relationship between hearths, neighbors, residents and occupants, which vary between 3.85 and $4.6^{\prime \prime}{ }^{6}$

The author presents two hypotheses with something in common: the fact that the period from 1580 to 1620 witnessed a slowdown of the Portuguese population growth, which was followed, between 1620 and 1665, by a decline or stagnation. From the 1660s until the early 18th century, the growth would have occurred at an average rate of $0.43 \%$. The 1600 s were marked by factors that combined to reduce the demographic dynamics: political instability, climate change and poor harvests, as well as spread of contagious and deadly diseases.

A witness to this scenario in the middle of the 17th century, Manuel Severim de Faria (1583-1655), in a chapter whose suggestive title is "how do people naturally multiply, while the people in this kingdom have been decreasing from the 1500s until now, and the reasons why", said:

From our colonies of the Terceira and Madeira Islands, this Kingdom has been rescued many times, with people and horses, and with a lot of wheat. Innumerable people have been taken from Angola, serving not only in the sugar farms of Brazil, but also in this Kingdom, both in the cultivation of the field and in ordinary service. From the population of Brazil, the sugar economy has arisen, in such abundance that we can supply almost all of Europe with it. Hence, we see that these colonies are not so harmful, because they don't take many people away from us. However, the conquest of India did not happen that way; being so many thousand leagues distant from Portugal, and with such dangerous navigation, it was necessary to take many people away from the Kingdom, with very little or none of them returning, because they tried to populate many cities on the borders of the most powerful princes of the east. ${ }^{7}$

As one can conclude, in his assessment, Brazil was not on the list of those responsible for the reduction of the Portuguese population, which, in 1640, would be equal to that found in 1527-1532. By comparison, the population of Brazil was far behind in numbers than other colonized areas. In 1550, the population of Madeira would have reached to 200,000 inhabitants, of whom 3,000 were slaves.

${ }^{6}$ Teresa Rodrigues, Portugal nos séculos XVI e XVII: vicissitudes da dinâmica demográfica, Porto, Centro de Estudos da População, Economia e Sociedade, 2004 (working paper - first version on the history of the Portuguese population in the 16th and 17th centuries - study conducted under project POCI/DEM/57987/2004 "História da População Portuguesa: das grandes permanências à conquista da modernidade).

${ }^{7}$ Manuel Severim de Faria, Notícias de Portugal, Lisboa, A.I. Fonseca, 1740, p. 5;10-11. 
In the early 17th century, the population of the island stabilized as a result of economic difficulties, and it was converted into an exit zone. In relative terms, one can compare the population of Portuguese descent residing in Cape Verde in 1572, which would be around 12,600 inhabitants; 15,708 in 1582, reaching 30,397 souls in the early 1630 s. $^{8}$. Therefore, these elements contributed to increase the migratory process of the Portuguese population to Brazil at a very moderate level throughout the 17th century.

However, the main determinant of the population of African origin in Brazil was the number of slaves imported annually. This import, in turn, was determined by the demand of the sugar economy in particular. The available figures of slaves landed in Brazil during the 18th century show an uptick between mid-1630 and mid-1640, followed by a decline until the 1680s, when an increase in imports from Africa was observed again (Graph 1). However, from 1697, one can clearly observe increase in the uptrend, now explained by the advent of gold production.

\section{The inevitable conclusion is that the figures of Contreiras Rodrigues for the 17th century are not minimally acceptable}

It is even harder to measure the incorporation of indigenous peoples in the colonial society. Obviously, it is not about considering the total population of Indians at the time of arrival of the Portuguese, whose estimates range from 1 to 5 million people. ${ }^{9}$ The central issue is to find reasons to establish a minimally consistent number. The inclusion of people of Indian origin in colonial society had been conditioned, to a great extent, by three variables: the outbreaks of epidemics to which they were exposed periodically; extermination wars, reaching their climax during the second half of the 17th century in the War of the Barbarians; and their enslavement, initiated principally by the Bandeirantes. ${ }^{10}$

\footnotetext{
${ }^{8}$ Maria Luísa Pinto; Teresa Maria Ferreira Rodrigues, Aspectos do povoamento das ilhas da Madeira e Porto Santo nos séculos XV e XVI, Atas do Terceiro Colóquio Internacional de História da Madeira, 1993, p. 403-471. ${ }^{9}$ The one million figure is attributed by Ángel Rosenblat, La población indigena de América desde 1492 hasta la actualidad, Buenos Aires, ICE, 1945; the 2.4 million figure, by John Hemming, Redgold: the conquest of the Brazilian Indians, 1500-1760, Cambridge, Harvard University Press, 1978 (by the way, a figure that the author himself takes as "pure guess-work" from the alleged depopulation rates of 28 regions in the country); the 4.8 million estimate was proposed by William M. Denevan, The Native Population of the Americas in 1492, Maddison, University of Winsconsin Press, 1976 (figures valid for the northern and central Brazil, including the Amazon). The problem with the latter is that the estimate was based on the agricultural potential, an inconsistent variable for a population of hunters and gatherers.

${ }^{10}$ On the epidemics, refer to Daniela Buono Calainho, "Jesuítas e medicina no Brasil colonial", Tempo, vol. 10, n. 19, 2005, p. 61-75, especially, p. 70-71; Stuart Schwartz, Segredos internos, São Paulo, Companhia das Letras, 1988, p. 51-52; 57-73. To these calamities, one should also add famine, according to John Manuel Monteiro, Negros da terra: índios e bandeirantes nas origens de São Paulo, São Paulo, Companhia das Letras, 1994, p. 157-158. On the War of the Barbarians, refer to Pedro Puntoni, A Guerra dos Bárbaros: povos indígenas e a colonização do sertão nordeste do Brasil, 1650-1720, São Paulo, Hucitec, 2002. In the words of the author (p. 17), "what we saw emerge during the War of the Barbarians was a new political orientation by the Portuguese Empire, carried to term by their colonial agents to produce the extermination of the indigenous nations of the northern hinterlands".
} 


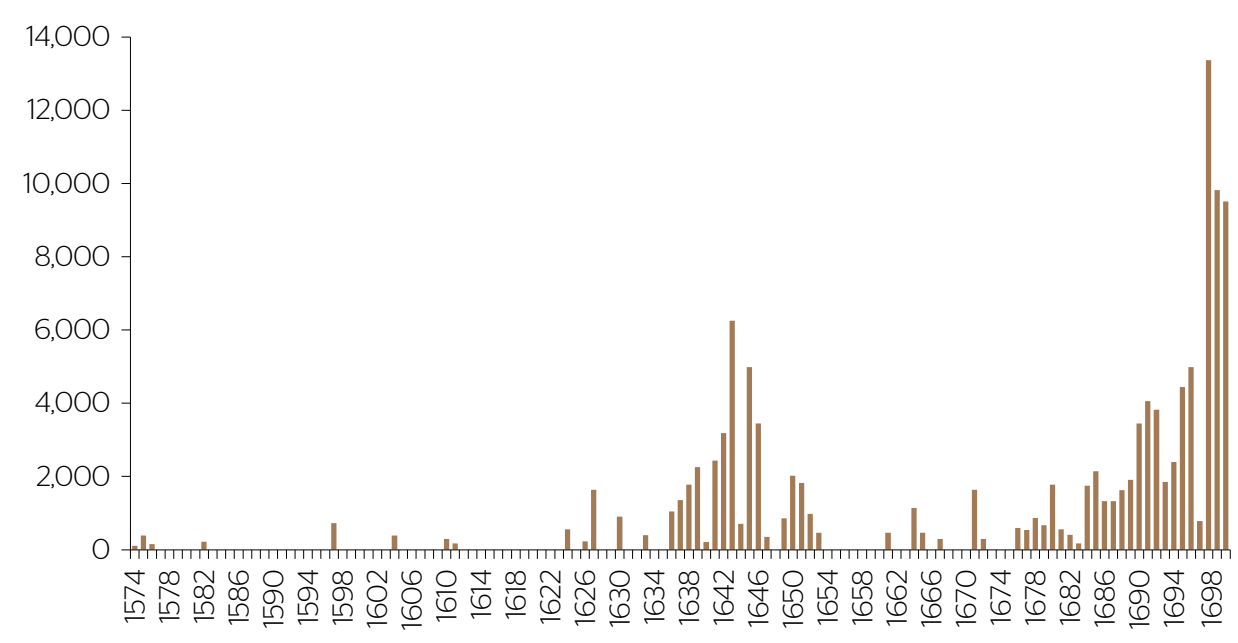

Source: Elaborated by the author, based on D. Eltis et al., The Transatlantic Slave Trade: a database on CDROM, Cambridge, Cambridge University Press, 1999. Disponível em:<http://www.slavevoyages.org/>. Acesso em: 15 de março de 2014.

Graph 1. Number of slaves landed in Brazil, 1574-1808.

The latter is the factor that actually contributes to the group's inclusion in the colonial population, but once they are enslaved, what is the percentage of that participation? In the evaluation of John Monteiro, "the survival rate of captives always remained very low in the period immediately following their arrest". ${ }^{11}$ Finally, one should consider the various indigenous villages undertaken by the Jesuits, in which, for the period of interest here, there was little advance. The same goes for the northern Portuguese America.

In summary, the evidence presented above indicates that the migration of the Portuguese population to Brazil occurred at a very moderate rate throughout the 17th century. Regarding the African population, the number of slaves who landed in Brazil would have experienced a considerable rise between the 1630s and 1640s, then falling to a level that remained relatively stable until the 1680s, when it again began showing a high trajectory, which accelerated strongly in the final years of the 1690s. Since it was clearly not a migration movement, but the import of goods that are directly or indirectly required for export-oriented production, the high and low rates of Africans landing in Brazil must be studied in the private economic situations. For the indigenous population, the picture is somewhat dismal, due to continuous reduction in their number.

Therefore, a review of the figures suggests that the starting point should be the authors of the last third of the 16th century: Gândavo, Anchieta, Cardim, and Francisco Soares (Table 1).

"John Manuel Monteiro, Negros da terra: índios e bandeirantes nas origens de São Paulo, São Paulo, Companhia das Letras, 1994, p. 157. 
Writing two years after Anchieta, Gabriel Soares de Souza shows figures that, although restricted to Pernambuco and Bahia, corroborate previous data. He calculated the population of Olinda to be 700 neighbors, but stressed that

Table 1. Population of Brazil, in hearths, 1570-1590

\begin{tabular}{|c|c|c|c|c|c|c|c|c|c|c|}
\hline \multirow{2}{*}{ Captaincies } & \multirow{2}{*}{1570} & \multicolumn{3}{|c|}{1583} & \multicolumn{3}{|c|}{1585} & \multicolumn{3}{|c|}{ ca, 1590} \\
\hline & & a & b & C & $a$ & b & c & d & b & c \\
\hline araíba & 100 & - & 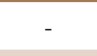 & - & 50 & - & - & 90 & 250 & - \\
\hline ern & 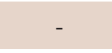 & - & - & - & 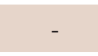 & - & - & 150 & 400 & - \\
\hline ahia & .000 & 1,000 & - & 2,000 & 1,110 & 10,000 & 2,000 & 2,000 & 18,000 & 2,000 \\
\hline héus & 1,100 & 3,000 & 3,500 & 8,000 & 2,000 & 3,000 & 8,000 & 1,500 & 18,000 & 3,600 \\
\hline ortc & 200 & 150 & - & - & 150 & - & - & 300 & 400 & 2,000 \\
\hline spí & 220 & 40 & - & - & 100 & 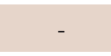 & - & 290 & 3,000 & 3,000 \\
\hline io d & 180 & 150 & - & - & 150 & - & 4,500 & 400 & 700 & 9,000 \\
\hline ão & 140 & 150 & 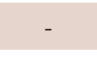 & 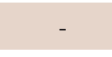 & 150 & 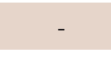 & 3,000 & 280 & 700 & 3,000 \\
\hline Dighbore & 500 & 330 & - & - & 300 & - & - & 600 & 800 & 6,000 \\
\hline izir & 3,440 & 4,820 & 3,500 & 10,000 & 4,010 & 13,000 & 17,500 & 5,610 & 42,250 & 28,600 \\
\hline
\end{tabular}

a: total of hearths (or, as more commonly shown in the sources, "neighbors") composed of Portuguese residents; b: total of African slaves; c: total of Christian Indians.

Sources: 1) For 1570: Pero de Magalhães Gândavo, Tratado da terra do Brasil, Belo Horizonte, Itatiaia, 1980, capítulos 1 a 9; 2) for 1583: Fernão Cardim, "Narrativa epistolar de uma viagem e missão jesuítica”, In: Fernão Cardim, Tratados da terra e da gente do Brasil, Rio de Janeiro, J. Leite, 1925, p. 279-415: "the city [of Bahia] has a population of 3,000 Portuguese neighbors, 8,000 Christian Indians, and 3,000 or 4,000 slaves from Guinea"; "the village of Nossa Senhora da Vitória [of Espírito Santo] will have over 150 neighbors with their vicar"; "the city [of Rio de Janeiro] has 150 neighbors with their vicar and many slaves of the land"; the Portuguese population of the captaincy of São Vicente was distributed through the villages of Piratininga ("120 neighbors with their slaves of the land" [p. 356]; "120 neighbors or more" [p. 359]); São Vicente, with 80; Santos, 80, and Itanhaém, 50; 3) for 1585: José de Anchieta (Padre), "Informação da Província do Brasil para nosso padre, 1585", In: ___ Cartas, informações, fragmentos históricos e sermões do padre José de Anchieta, S. J. (15541594), Rio de Janeiro, Civilização Brasileira, 1933, p. 409-447. This document corresponds to the translation of the manuscript in Spanish and writing contemporary of the 16th century from the Évora Library, published by Capistrano de Abreu - José de Anchieta, Informações e fragmentos historicos do padre Joseph de Anchieta, S.J. (1584-1586) [Pref. de João Capistrano de Abreu], Rio de Janeiro, Imprensa Nacional, 1886, p. VII e nota na p. 55-56 (Cartas jesuíticas; Folha de rosto adicional: "Materiaes e achegas para a Historia e Geographia do Brasil publicadas por ordem do Ministerio da Fazenda. n. 1, julho de 1886"). Capistrano maintains the authorship of Anchieta and the date -1585 , as well as discusses the patent similarity of various sections of the Information by Anchieta with the epistolary narrative of Fernão Cardim; the total of the captaincy of Pernambuco is the sum of the inhabitants of Olinda ("1,000 neighbors with its county of Portuguese people, with their vicar and other secular clergy") and Igaraçu ("110 white neighbors with their vicar"); about Salvador, he noted that the size of the population is "not very large, because most people live outside of their sugar mills and farms; it has, in its entire county, almost 2,000 Portuguese neighbors, for which there are 10,000 or 12,000 people for their service in the mills and farms [that is, servants]; there are up to 3,000 slaves from Guinea and approximately 8,000 Christian Indians of the land, among slaves and free"; the population of the captaincy of Porto Seguro was distributed in two villages: Santa Cruz, with 50 neighbors, and Porto Seguro, with 50; Espírito Santo: 150 neighbors; the Portuguese population of the captaincy of São Vicente was distributed through the villages of São Vicente (50 hearths), Santos (100), Itanagar (30 "white neighbors"), and Piratininga (120 hearths); 4) for ca. 1590: Francisco Soares, Coisas notáveis do Brasil, vol. 1, Rio de Janeiro, Instituto Nacional do Livro, 1966, p. 11. Originally published in bibliographic archive of the Library of the University of Coimbra (current title: Boletim da Biblioteca da Universidade de Coimbra), vol. 4, Coimbra, Imprensa da Universidade de Coimbra, 1904, as well as in the Revista do Instituto Histórico e Geográfico Brasileiro, vol. 2, 1923, p. 367-421.

Note: Harold Johnson gives a figure of 12,000 people for Pernambuco in 1585 and assigns six individuals to each hearth. Harold Johnson, "The Portuguese settlement of Brazil, 1500-1580", In: Leslie Bethell, Cambridge History of Latin America, vol. 1, Cambridge, Cambridge University Press, 1984, p. 279. 
there could be many more neighbors, because in each of these sugar farms live twenty to thirty neighbors, aside from those who live outside in fields, away from them, which is a lot of people; so if necessary to join these people in arms, they can add up to more than three thousand men of war on the field, with the residents of Cosmos town [Igarassu], among which there will be 400 men riding horses. These people can bring four or five thousand slaves from Guinea from their farms and many heathens of the land.

Similarly, for Salvador, he estimated a population of about 800 neighbors, but stressed that

outside it, in all the reconcaves of Bahia, there will be more than two thousand neighbors, which can be incorporated to the city's inhabitants. When that happens, there will be five hundred men on horses and more than two thousand on foot, as well as the people on the ships that are always in the harbor. ${ }^{12}$

\footnotetext{
Brazil was not on the list of those responsible for the reduction of the Portuguese population, which, in 1640, would be equal to that found in 1527-1532
}

In view of the more detailed figures by Anchieta, they are the ones taken as a starting point in this study for estimating the population in the late 16th century, which constitutes around 60,000 inhabitants in 1585. Unfortunately, this is exactly what it is: a starting point, because, since then, we could not count on information of equal quality. Around the year 1590, figures that "according to... [his] memory" were estimated by Father Francisco Soares resulted in a much higher number, nearly 100,000 individuals, among Portuguese $(28,050)$, slaves $(42,250)$, and Indians $(28,600)$. It is an apparently inflated number, judging by the number of hearths from both Portuguese people and slaves.

From the beginning of the 17th century, there are two sources that show largely similar figures. According to Diogo de Campos Moreno, Ilhéus counted 250 inhabitants (word used as a synonym for neighbors) in 1611. About Bahia, Moreno pointed out: "this Reconcave is the most populated location in the entire coast, and in it, in their farms, live noble people, surpassing 3,000 white residents". In Sergipe, the total would be 200, and in Pernambuco it would be 4,000. Finally, there is Paraíba, that had "on their sugar farms and plantations [there would be] more than 700 white residents, who, with their slaves and families, make up a great number". Its capital, Filipéia, counts 80 white neighbors, as well

12Gabriel Soares de Souza, Tratado descritivo do Brasil em 1587, Rio de Janeiro, J.I. da Silva, 1879, p. 23;109. 
as the 8 Indian villages, "copious with people, administered by the doctrine of the priests, Francis and Benedicts". ${ }^{3}$

Another more geographically comprehensive document informs us that, in Rio Grande do Norte, lived "30 neighbors... out of livestock, farming and fishing”, with tithes reaching the value of $250 \$ 000$ réis. In Paraíba, "100 Portuguese neighbors" resided, and "in its district ... over 800 Portuguese" resided, which were spread over 14 or 15 sugar farms. Besides these, there were "more than 14,000 potiguar heathens of the land" and other nations "divided by their villages, which were maintained by minor Franciscan friars". Sugar production yielded 6,000-7,000 arrobas. Itamaracá was the residence of 500 white inhabitants, which produced 2,500 arrobas of sugar. The population of Pernambuco increased to "more than 4,000 Portuguese people in its district" yielding tithes of 23,000 arrobas of sugar. Sergipe had 50 residents, and Bahia had 3,000 Portuguese people. Sugar production would yield 14,000 arrobas. Ilhéus would not have more than 100 residents and, in Porto Seguro, only 40 residents lived out of "flour of the cassava that they plow there, along with some vegetables". For Espírito Santo, it just informs that sugar production reached 1,500 arrobas, the same output of Rio de Janeiro, which, in turn, would have "more than six hundred Portuguese residents". In the last captaincy, São Vicente, there lived over 700 Portuguese residents who produced 800 arrobas of sugar. ${ }^{14}$

Judging by the numbers mentioned by Diego Moreno, in 25 years, there would have been a sharp increase in the population of Bahia (50\%), Ilhéus (66\%), Paraíba and, even more remarkably, of Pernambuco, which quadrupled its Portuguese population. This growth allows us to infer a total population of at least 80,000 inhabitants consisting of Portuguese, Christian Indians, and African slaves. Except for Ilhéus, the period from 1585 to 1612 (the year of the writings of Diogo Moreno) actually coincides with a dramatic increase in Northeastern sugar production, measured both by the number of sugar farms (Table 2) and the collection of tithes.

\footnotetext{
${ }^{13}$ Diogo de Campos Moreno, Livro que dá razão ao Estado do Brasil [1612], Critical Edition, with introduction and notes by Hélio Viana, Recife, Arquivo Público Estadual, 1955. The total of 4,000 residents - hearths in Pernambuco was registered in the Port's codex, because the apograph. of the Brazilian Historical and Geographical Institute presents the double of that figure. The reason would be, in the judgment of Hélio Viana, in the fact that the copies of Rio de Janeiro have updated the data between 1625 and 1627. The same goes for the captaincy of Itamaracá, whose residents would be more than 500, according to a copy of the Historical Institute.

${ }^{14}$ Arquivos Nacionais/Torre do Tombo, Miscelâneas Manuscritas do Convento da Graça, tomo VI F, fls. 147158, "Província do Brasil". There is a copy at the Biblioteca da Ajuda (Lisboa), 51-IX-25. Artur Teodoro de Matos proposes a date ca. 1607 for this document. In fact, the text mentions Francisco de Aguiar Coutinho as captain-major of the Espírito Santo captaincy, from 1605 on, and Lopo de Souza, who died in 1610, as captainmajor of the captaincy of São Vicente. But, in the section on Bahia, the document states that "His Majesty has here a new deal with the Biscainhos who fish whales". Now, whaling was made a royal monopoly from 1616, but it was already the object of contract in Bahia from 1614 (Artur Teodoro de Matos, "O império colonial português no início do século XVII: elementos para um estudo comparativo das suas estruturas económicas e administrativas", Arquipélago. História, 2a série, vol. 1, n. 1, 1995). In this regard, refer to Angelo Alves Carrara, Receitas e despesas da Real Fazenda no Brasil, século XVII, Juiz de Fora, Editora da UFJF, 2009, p. 32-33. Therefore, the document must have been produced just a bit later to the text of Diogo Moreno.
} 
Table 2. Number of sugar farms in Brazil, 1570-1629

\begin{tabular}{lccccc} 
& 1570 & 1583 & 1589 & 1612 & 1629 \\
\hline Ilhéus & 8 & 3 & 6 & 5 & 4 \\
\hline Bahia & 18 & 36 & 50 & 50 & 80 \\
\hline Pernambuco & 23 & 66 & 70 & 90 & 150 \\
Itamaracá & 1 & 0 & 2 & 10 & 18 \\
Paraíba & 0 & 0 & 2 & 12 & 24 \\
Total & 50 & 105 & 130 & 167 & 276
\end{tabular}

Sources: Stuart Schwartz, Segredos internos, São Paulo, Companhia das Letras, 1988, p. 148; Francisco Soares (Padre), Coisas notáveis do Brasil - 1590, vol. 1, Rio de Janeiro, Instituto Nacional do Livro, 1966, p. 11 (para 1589).

The reduction in the number of sugar farms in Ilhéus does not seem to indicate major problems, since its economy was not based on sugar production, but on the production of cassava flour to supply the Reconcave, as demonstrated by Marcelo Dias. ${ }^{15}$ Thus, population growth would be a blunt reflection of the expansion of sugar cane farming and of the economic production directly linked to sugar production. The growth in the number of sugar farms would have been $40 \%$ in Bahia and $73 \%$ in Pernambuco between 1583 and 1612, which is closer to the figures mentioned by Anchieta. Itamaracá and Paraíba, in turn, would witness a rapid growth. This strongly upward movement could have been maintained until at least the eve of the Dutch invasion of Pernambuco.

As for the total amount collected from tithes, a strong increase is observed between 1608 and 1621, which is another evidence showing a sharp increase in population during that period: in 1608, the tithes of Bahia reached the figure of 15:200\$000 réis, and those of Pernambuco reached 25:700\$000 réis; in 1621, the tithes of Bahia had already reached the figure of $67: 100 \$ 000$ réis, that is, more than four times the amount over 13 years. But the sharp rise in the collection of tithes (i.e., sugar production) between 1608 and 1621 was interrupted by a severe crisis in 1621-1622, whose recovery took 20 years. ${ }^{16}$

If, during the period of high sugar production, a significant population growth occurred, this did not attract the attention of Friar Vicente Salvador, who reported "200 neighbors" in the town of Recife in around 1627. ${ }^{17}$

For the second half until the end of the 17th century, we rely on sparse information, but in any case valuable in the absence of better-quality information. In the mid-17th century, Father Antonio Vieira estimated the slave population in Brazil to be 35,000 individuals, distributed over a total of 200 sugar mills and farms, of which 170 were "mills of Rio de Janeiro, or engenhocas, as they call

\footnotetext{
${ }^{15}$ Marcelo Henrique Dias, Economia, sociedade e paisagens da capitania e comarca de Ilhéus no período colonial, Tese de doutorado, Universidade Federal Fluminense, Niterói, 2007.

${ }^{16}$ Angelo Alves Carrara, Receitas e despesas da Real Fazenda no Brasil, século XVII, Juiz de Fora, Editora da UFJF, 2009, p. 80-81; 125 .

17Vicente do Salvador (Frei), História do Brasil, Rio de Janeiro, Irmãos Weiszflog, 1918, p. 106
} 
them there, three of which do not equal the production or the income of one mill of Minho grapes". ${ }^{18}$ The number of slave population had increased three times by 1585 .

From 1656-1657,

tithes were experiencing regular uptrend, with natural bumps determined by better or worse crops. But the undeniable fact is the steady and persistent growth trend. This trend abruptly declined in 1687, not by a change in prices, but due to an epidemic that disrupted production for years. ${ }^{19}$

But let us not exaggerate this long-term trend: the second half of the 17th century witnessed economical and fiscal stagnation. The value of the tithes in 1655-1656 (over 46 million réis) was only surpassed in 1695-1696 when they reached 60 contos de réis. ${ }^{20}$

The period after the Dutch invasion must have seen a depopulation of the northern captaincies by Portuguese settlers who went to Bahia or Rio de Janeiro. ${ }^{21}$ The Pernambuco Restoration must have immediately set off a rearrangement of the population, with a negative migration flow to Bahia and parts of the south and a positive migration flow to the northern captaincies, which had little influence on Brazil's total population.

Thus, a century of wars (1624-1625, the invasion and occupation of Salvador by the Dutch; 1630-1654, Dutch invasion and occupation of northern captaincies; from 1651, the war of the barbarians; in 1680, founding of the Colonia do Sacramento), an economic crisis in the sugar industry and, by the end of the 1600 s, a cholera outbreak acted as strongly limiting factors for population growth.

In the last quarter of the 17th century, we have, for the captaincy of Rio de Janeiro, the statements of the witnesses presented at the proceedings of the Holy See for its elevation to the rank of bishopric. ${ }^{22}$ The witnesses were Rodrigo do Espírito Santo, priest of the Order of St. Benedict and Attorney General of Portugal and Brazil at the Roman Curia; the Jesuit Father Antonio Gonçalves; also the Jesuit Antonio Vieira and the abbot Martinho Mesquita. The inquiry and

\footnotetext{
${ }^{18}$ Antônio Vieira (Padre), "Parecer do padre Antônio Vieira sobre se restaurar Pernambuco e se comprar aos holandeses; Lisboa, 14 de março de 1647", In: 1856, p. 159-176.

${ }^{19}$ Angelo Alves Carrara, Receitas e despesas da Real Fazenda no Brasil, século XVII, Juiz de Fora, Editora da UFJF, 2009, p. 117.

20/bidem, p. 126-127.

${ }^{21}$ According to Evaldo Cabral de Mello (Olinda restaurada: guerra e açúcar no Nordeste, 1630-1654, 2. ed., Rio de Janeiro, Topbooks, 1998 [1975], p. 389-90), "in Rio de Janeiro, the people from the Northeast also established themselves with plantations and sugar mills and farms [...]. The new prosperity through which Rio de Janeiro was going no longer had to do with the trade with Rio da Prata, which will be reduced from 1640 on, but, as it was intended in Bahia, with the émigrés who had built mills on the seaside and along river banks". According to this author, Rio de Janeiro offered greater advantages than Bahia, namely, cheaper lands that were relatively preserved from the damage that the Dutch wars brought to the trade and navigation of Brazilian sugar.

${ }^{22}$ Archivum Secretum Vaticanum, Archivum Consistorialis, Acta Congregationis Consistorialis, vol. 1, 13 de março de 1674, fls. 89-141. It is a set of documents, mostly in Latin and Italian, composed of a memorial, the inquiries and answers from witnesses, the process, and letters of the nuncio in Lisbon.
} 
the answers were approved between September and October 1673. However, Father Antonio Vieira is described to be 64-years old at the time. As he was born in February 1608, the inquiry must have occurred in $1672 .{ }^{23}$

Of the total of 23 questions in the interrogation, those that precisely refer to the number of hearths and souls of the different towns and villages that were under the jurisdiction of the new bishopric are of special interest for the present study.

Of the four witnesses mentioned earlier, only Rodrigo do Espírito Santo and Father Vieira provide more accurate information, but the accounts of the former seem to be more consistent. In their responses, both Father Antônio Gonçalves and Abbot Martinho Mesquita affirm not knowing or just believing the accuracy of the inormation. ${ }^{24}$

\section{The period after the Dutch invasion must have seen a depopulation of the northern captaincies by Portuguese settlers who went to Bahia or Rio de Janeiro}

In the evaluation by Rodrigo do Espírito Santo, there would be 3,000-4,000 souls in three parishes: São Sebastião (mother), Nossa Senhora da Candelária, and São José. ${ }^{25}$ It would include "numerous clergy, both secular and regular, approximately 250-300", and "many noble landowners, captains and people of high ranks, doctors and teachers and other people who make the place conspicuous and live off their own income and their own farms" (emphasis added). Besides the city of São Sebastião, he notes that Cabo Frio, "currently destroyed, because it was occupied by the Dutch and plundered by them", had two churches and a little over 100 souls. Other places would count with the rule of a captain (that is why the witness speaks of "captaincies"), such as Porto Seguro, Espírito Santo, Ilha Grande, Ilha de São Sebastião, São Vicente, Parnaguá, and Vila da Conceição, were "densely populated". In São Paulo, there would be 1,500 white Christians and more than 10,000 slaves. Santos counted a thousand white Christians and somewhere between 3,000 and 4,000 slaves.

\footnotetext{
${ }^{23}$ Rodrigo do Espírito Santo He served later as commissioner of the Holy Office in Bahia. About this subject see. Grayce Mayre Bonfim Souza, Para remédio das almas: comissários, qualificadores e notários da Inquisição portuguesa na Bahia (1692-1804), Tese de doutorado, Universidade Federal da Bahia, Salvador, 2009, p. 70; 175-176; 186-187.

${ }^{24}$ Originally: "nescio precise sed credo"; the statement by Antônio Gonçalves that he had never entered the mother church of the city of Rio de Janeiro is very representative ("nunquam ingressus fuithanc ecclesiam"; fl. 95r). On the lack of numbers to be presented, "nescit precise numerum animarum"; and about Cabo Frio, "non intrasse civitatem de Cabo Frio". The same goes for the testimony by abbot Mesquita, which showed an even higher impossibility to present precise data.

${ }^{25}$ Numbers, in fact, superior to those presented by Antônio Gonçalves, for whom the total population would be around 2,000 ("duo millia foculariorum", Archivum Secretum Vaticanum, Archivum Consistorialis, Acta Congregationis Consistorialis, vol. 1, 13 de março de 1674, fl. 95r).
} 
Elsewhere, the size of the population was smaller, and he affirmed this "for having been there".

In turn, Antônio Vieira presented higher figures than Rodrigo do Espírito Santo for the city of Rio de Janeiro: 4,000-5,000 Portuguese souls, and 20,000 African slaves and indigenous people, seeking to corroborate his claim by having been "in the region for over twenty years". He emphasized that although he "had not been to the same town of São Sebastião [of Rio de Janeiro]", he had reports of priests of the town's Jesuit College, besides other Portuguese people. ${ }^{26} \mathrm{He}$ also stated that the number of churchmen exceeded 200. Of the remaining Portuguese colonies included in the future jurisdiction of the bishopric, he listed Porto Seguro, Espírito Santo, Cabo Frio, Ilha Grande, São Paulo, São Vicente, Santos, Cananéia, and other smaller ones up until the Rio da Prata, all of them with parish priests and vicars. São Paulo and Espírito Santo had other monasteries of religious people and 13-14 Indian villages with their churches, "all Christians, like all servants of the Portuguese, be them Indians or Africans". ${ }^{27}$ So far, the testimony of Vieira does not seem to present major differences from the previous one. It is in the total number for the whole captaincy that a deep discrepancy appears. Vieira presents a figure of "more than 200,000 souls". ${ }^{28}$ The fact that Vieira has not actually collected information in loco, as he was absent from Brazil for over a decade and had second-hand information, even if it came from members of his own congregation, makes the data he presented less consistent than those of Friar Rodrigo. In the particular case of the number of inhabitants of the city of Rio de Janeiro, there is considerable variation: a lower number of 2,000 souls proposed by Antônio Gonçalves, 3,000-4,000 by Friar Rodrigo, and 4,000-5,000 souls, by Father Vieira. To these, another 3,000 souls can be added up as this is the figure presented by apostolic nuncio and Archbishop of Chalcedon, Marcelo Durazzo, in a letter written in Lisbon dated May 2, 1673. ${ }^{29}$

Owing to them being more detailed and substantiated information, the figures taken here are referred by Rodrigo do Espírito Santo as more consistent. That is: a) for the city of Rio de Janeiro 3,000-4,000 inhabitants; although, in his testimony, he did not provide a figure for the number of slaves, it can be compensated by the value given by Vieira (20,000 slaves). With this, we would reach a total of 23,000-24,000 people for Rio de Janeiro;

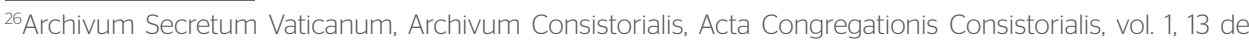
março de 1674, fl. 96v: "quatuor vel quinque millia animarum ex Lusitanis verumtamen, ex ipsis Brasilianis et Angolanis qui sunt Etiopes[sic] et servi christiani tamen amplecti viginti circa millia animarum, et h[a]ec scire quia fui in illa regione viginti et amplius annos, et quamvis non fuerim in ipsa civitate S. Sebastiani, nihil h[a] ec audivi publice, et palam ex continuo co[m]mercio cum patribus societatis ex quo in ibi adest Collegium et cum aliis Lusitanis et est publicum et notorium".

${ }^{27}$ Ibidem, fl. 96v: "qui omnes sunt christiani sicut etiam omnes servi Lusitanorum tam ex Brasiliensibus quam ex Angolanis"

${ }^{28} / \mathrm{bidem}$, fl. 97r: "magnitudo totus status iuxta oram maritimam extenditur cir[cite]r per tria millia milliarum et ultra, versus mediterraneum verum nullus habet limites[...] numerus autem omnium Christianorum excedit ducenta millia".

29/bidem, fls. 89-141; 131r.
} 
b) for São Paulo, with just under 12,000 (1,500 whites and the rest were Indians and African slaves); and

c) for Santos, with about 5,000 inhabitants (among them 1,000 were whites and the others were slaves).

Altogether, one can infer a minimum of 40,000 and a maximum of 50,000 inhabitants along the extensive strip from Espírito Santo to Paranaguá. The number of 200,000 indicated by Vieira seems reliable, with the possible Christianization of the Indians of the Rio Uruguay basin.

These figures become more consistent if we consider the detailed numbers of each of the parishes of the bishopric of Rio de Janeiro recorded on a pastoral visit in 1687 (Table 3). The numbers appear to cover the population of Portuguese, African and indigenous origin. This is very clear in the case of the parish of São Gonçalo, to which was assigned the total of 250 hearths. If we apply the rule of six people per household, the parish would have 1,500 individuals, which is just the total shown in the document, detailing 800 white communicants and 700 slaves; the same goes for Nossa Senhora da Pena de Porto Seguro, whose 141 households would result in 846 individuals. The total presented was, however, of 745 , corresponding to 495 whites and 250 slaves. However, further studies should clarify the wide disparities in the relationship between the number of communicants and the number of hearths recorded in the parishes of São Francisco do Sul and Jacareí, on one side, and Cotia and Iguape, on the other.

Considering the total population (and not just communicants), the document states that, in the parish of Candelaria, with 600 households, there were 3,500 souls, of which 2,800 were communicants (i.e., $80 \%$ of residents in the parish); in São João da Barra de Paraíba, 22 white couples accounted for 200 souls, of which 150 were communicants, that is, $75 \%$ of all residents. If, indeed, this proportion is valid, the total population in the area between Porto Seguro and São Francisco do Sul would be between 50,000 and 53,000 individuals in the late 1680s. ${ }^{30}$

For Maranhão, the same document contains only a summary of the testimonies, which simply indicated that São Luís was "very numerous in population", as well as some other places that were "highly populated with heathens"."1

In the early 1680s, Chief Judge Sebastião Cardoso de Sampaio noted that the State of Brazil was then "so enlarged, that the city of Bahia has more than 3,000 neighbors, and the Reconcave and the backcountry had countless people".32 This would mean that the city of Salvador must have had between 12,000 and 15,000 people.

\footnotetext{
$\overline{30}$ Victor Oliveira got to a total 18,578 people in all parishes of the captaincy of Rio de Janeiro, except Angra dos Reis and Parati (Victor Luiz Álvares Oliveira, "Filhos naturais e elites das senzalas: compadrios e hierarquias sociais em uma freguesia rural do Rio de Janeiro (1691-1721)", Revista 7 Mares, n. 4, 2014, p. 59-76). This total includes 3,500 souls of the Candelaria parish, and not the 2,800 communicants.

${ }^{31}$ Archivum Secretum Vaticanum, Archivum Consistorialis, Acta Congregationis Consistorialis, vol. 1, 13 de março de 1674, fls. 89-141; 117r-123r.

${ }^{32}$ Arquivo Histórico Ultramarino (AHU)/BA, Papel que fez o desembargador Sebastião Cardoso de Sampaio, [no] tocante às coisas da Fazenda e Justiça e governo do Brasil, Lisboa, 16 de janeiro de 1681 (Série Luísa da Fonseca, cx. 24, doc. 2972).
} 
Table 3. Population of the parishes and chapels with resident priests of the bishopric of Rio de Janeiro by parish, 1687

\begin{tabular}{|c|c|c|c|}
\hline & $\mathrm{H}$ & C & $\mathrm{C} / \mathrm{H}$ \\
\hline \multicolumn{4}{|l|}{ Rio de Janeiro } \\
\hline Sé & 650 & 3,500 & 5,38 \\
\hline Candelária & 600 & 2,800 & 4,67 \\
\hline Santo Antônio de Macacu [or do Caceribu] & 167 & 1,037 & 6,21 \\
\hline Santíssima Trindade & 60 & 500 & 8,33 \\
\hline Nossa Senhora do Desterro de Itambi & 95 & 693 & 7,29 \\
\hline São João de Itaboraí & 91 & 382 & 4,20 \\
\hline Nossa Senhora da Piedade de Magé & 148 & 547 & 3,70 \\
\hline São Nicolau de Suruí & - & 400 & - \\
\hline Nossa Senhora da Guia de Pacobaíba & 71 & 448 & 6,31 \\
\hline Santo Antônio [de Iguaçu] & 100 & 212 & 2,12 \\
\hline Nossa Senhora da Piedade de Inhomirim & 60 & 300 & 5,00 \\
\hline Nossa Senhora da Apresentação de Irajá & 200 & 1,800 & 9,00 \\
\hline São João de Meriti & - & - & - \\
\hline Nossa Senhora da Conceição de Marapicú & 65 & 396 & 6,09 \\
\hline Nossa Senhora da Ajuda de Guapimirim & 49 & 330 & 6,73 \\
\hline São Tiago de Inhaúma & 75 & 550 & 7,33 \\
\hline Nossa Senhora do Loreto de Jacarepaguá & 186 & 400 & 2,15 \\
\hline Nossa Senhora do Desterro de Campo Grande & 70 & 313 & 4,47 \\
\hline Santo Antônio de Inhoaíba & 30 & 150 & 5,00 \\
\hline São Gonçalo & 250 & - & - \\
\hline São João de Icaraí & 134 & 1,420 & 10,60 \\
\hline São Sebastião de Itaipu & 20 & 50 & 2,50 \\
\hline Nossa Senhora do Bonsucesso de Piratininga & 18 & 170 & 9,44 \\
\hline Nossa Senhora da Assunção de Cabo Frio & 81 & 459 & 5,67 \\
\hline São Salvador dos Campos & 150 & 800 & 5,33 \\
\hline São João da Barra de Paraíba & 22 & 150 & 6,82 \\
\hline Nossa Senhora de Nazaré de Saquarema & 60 & 150 & 2,50 \\
\hline Nossa Senhora do Amparo de Maricá & 70 & 180 & 2,57 \\
\hline Vila de Angra dos Reis da IIha Grande & 152 & 606 & 3,99 \\
\hline Vila de Parati & 65 & 240 & 3,69 \\
\hline Subtotal & 3,739 & 18,983 & 5,07 \\
\hline \multicolumn{4}{|l|}{ Espírito Santo } \\
\hline Nossa Senhora da Vitória do Espírito Santo & 288 & 2,026 & 7,03 \\
\hline Vila Velha do Espírito Santo & 60 & 200 & 3,33 \\
\hline Nossa Senhora da Conceição de Guarapari & 34 & 270 & 7,94 \\
\hline Aldeia de índios em Guarapari & 200 & 400 & 2,00 \\
\hline Subtotal & 582 & 2,896 & 4,97 \\
\hline \multicolumn{4}{|l|}{ Porto Seguro } \\
\hline Nossa Senhora da Pena de Porto Seguro & 141 & 745 & 5,28 \\
\hline Santa Cruz do Porto Seguro & 47 & 285 & 6,06 \\
\hline Aldeia de índios em Santa Cruz do Porto Seguro & 32 & 77 & 2,41 \\
\hline Santo Antônio de Caravelas & 60 & 120 & 2,00 \\
\hline Subtotal & 280 & 1,227 & 4,38 \\
\hline
\end{tabular}


Table 3. Continuation

\begin{tabular}{|c|c|c|c|}
\hline & $\mathrm{H}$ & $\mathrm{C}$ & $\mathrm{C} / \mathrm{H}$ \\
\hline \multicolumn{4}{|l|}{ São Paulo } \\
\hline Vila de São Paulo & - & 1,520 & - \\
\hline Santo Amaro & 118 & 740 & 6,27 \\
\hline Nossa Senhora do Monserrate [de Cotia] & 72 & 100 & 1,39 \\
\hline São João [de Atibaia] & 147 & 457 & 3,11 \\
\hline Nossa Senhora do Desterro [de Mairiporã] & 43 & 200 & 4,65 \\
\hline Nossa Senhora da Conceição [de Araçariguama] & 65 & 430 & 6,62 \\
\hline Vila de Jundiaí & 69 & 309 & 4,48 \\
\hline Vila de Jacareí & 144 & 4,010 & 27,85 \\
\hline Vila de Taubaté & 353 & 1,400 & 3,97 \\
\hline Vila de Santo Antônio de Guaratinguetá & 61 & 250 & 4,10 \\
\hline Vila de Pindamonhangaba & 56 & 152 & 2,71 \\
\hline Vila de Mogi & 296 & 692 & 2,34 \\
\hline Vila de Itu & 300 & 2,000 & 6,67 \\
\hline Vila de Sorocaba & 75 & 300 & 4,00 \\
\hline Vila de Parnaíba & 300 & 900 & 3,00 \\
\hline Vila de Ubatuba & 67 & 242 & 3,61 \\
\hline Vila de São Sebastião & 125 & 500 & 4,00 \\
\hline Vila de São Vicente & 70 & 400 & 5,71 \\
\hline Vila de Santos & 170 & 500 & 2,94 \\
\hline Vila da Conceição & 70 & 500 & 7,14 \\
\hline Vila de Iguape & 67 & 96 & 1,43 \\
\hline Vila de Cananeia & 57 & 290 & 5,09 \\
\hline Subtotal & 2,725 & 15,988 & 5,87 \\
\hline \multicolumn{4}{|l|}{ Santa Catarina e Paraná } \\
\hline Vila do Rio de São Francisco [do Sul] & 17 & 370 & 21,76 \\
\hline Vila de Paranaguá & 168 & 470 & 2,80 \\
\hline Curitiba & 37 & 150 & 4,05 \\
\hline Subtotal & 222 & 990 & 4,45 \\
\hline Total & 7,548 & 39,922 & 5,29 \\
\hline
\end{tabular}

Source: Arquivo da Cúria Metropolitana do Rio de Janeiro/Série de Visita Pastoral/Notícias do Bispado do Rio de Janeiro no ano de 1687 [Visitas Pastorais - VP-38].

$\mathrm{H}$ : hearths; C: communicants; $\mathrm{C} / \mathrm{H}$ : ratio between the number of communicants and the number of hearths. Notes: 1) this document finds itself restricted because of the extreme fragility of the support, which is why a transcription was made, available in the Archives of the Metropolitan Curia in Rio de Janeiro; 2) the document does not show the number of hearths and communicants in the parish of São João de Meriti; 3) the total number of hearths of São Nicolau de Suruí, currently the city of Magé, is eroded in the manuscript; 4) for São Gonçalo, the document discriminates 800 white communicants and 700 slaves; 5) in Nossa Senhora da Vitória do Espírito Santo, the total of 2,026 corresponds to white and black residents; 6) in Nossa Senhora da Pena de Porto Seguro, the total corresponds to 495 whites and 250 slaves; 7) for the indian village in Santa Cruz do Porto Seguro, the document records 32 hearths and 77 "Indians of the land"; 8) instead of "hearths", the document refers to "couples" in São João da Barra da Paraíba, Santo Antônio de Caravelas and Guarapari. 
In the last decade of the 17th century, however, we have far more robust estimates: the result of two pastoral visits in the Diocese of Olinda in 1693 and 1701 (Table 4). In the first case, the total population would be between 53,000 and 66,000; in the second, between 55,000 and 68,000. In one decade, the population under the jurisdiction of the bishopric of Olinda would therefore have experienced growth of about $3 \%$.

\section{While the number of Brazilian inhabitants proposed by Rodrigues Contreiras for the 16th century does not differ from that shown by other important authors referred, it changes considerably in the 17th century}

Moreover, taking into account the economic picture in the second half of the 18th century, which is characterized by relative stability in the production of the main farm products - values of the deflated tithes remain strictly at the same levels in 1650 - , the figures available for Rio de Janeiro for 1673 and Bahia for 1681 might not have suffered variation. ${ }^{33}$ Maybe, the figure indicated by Anchieta, who claimed that the population of the captaincy of Bahia correspond to two-and-a-half times the population of Salvador, which would, from the numbers seen earlier, be 7,500 hearths by Portuguese people in 1680, or 45,000 people (six people per hearth), would not be true anymore. This figure is very small indeed when compared with that of Pernambuco, even 10 years later. But one should remember what was highlighted previously with respect to the limiting factors of population growth in the second half of the 17th century. Now, if some relationship could be established between the total agricultural production of the three captaincies (Bahia, Pernambuco, and Rio de Janeiro) between 1670 and 1700, which can be measured by the value of the tithes, even though they express, almost in its entirety, the production destined for export, then the figures of Bahia in 1680, from Pernambuco in 1693 and 1701, and from Rio de Janeiro in 1673 would yield more agreement than disagreement. Bahia and Pernambuco together are responsible for at least three quarters of the total population of Brazil, with the captaincy of Rio de Janeiro representing the remaining quarter. For the final years of the 17th century, assigning a maximum of 70,000 people to both Pernambuco and Bahia, and 40,000-50,000 people to the whole area comprehended by the bishopric of Rio de Janeiro, one would get a number much higher than 200,000 individuals.

${ }^{33}$ In this respect, refer to the analysis, based on the total collection of tithes, by Angelo Alves Carrara, Receitas e despesas da Real Fazenda no Brasil, século XVII, Juiz de Fora, Editora da UFJF, 2009, p. 80-81; 85. 
Table 4. Number of hearths in the bishopric of Pernambuco, 1693-1701

\begin{tabular}{|c|c|c|}
\hline & 1693 & 1701 \\
\hline \multicolumn{3}{|c|}{$\begin{array}{l}\text { Strip I - from Paraiba to the North of Alagoas: } 300 \text { km of coast between } \\
\text { Mamanguape and Camaragibe }\end{array}$} \\
\hline Mamanguape & 130 & 90 \\
\hline Two small Indian villages & 70 & \\
\hline Paraíba & 1,600 & 1,650 \\
\hline Taquara & 150 & 200 \\
\hline Desterro (currently Itambé) & 72 & - \\
\hline Goiana & 600 & 600 \\
\hline Tejucopapo & 208 & 180 \\
\hline Itamaracá & 160 & 280 \\
\hline Igarassu & 400 & 600 \\
\hline Tracunhaém & 100 & 260 \\
\hline São Lourenço da Mata & 850 & 450 \\
\hline Aldeia de Limoeiro (85 km from Recife) & 20 & - \\
\hline Aldeia de Araribá (200 km from Recife) & 50 & - \\
\hline Nossa Senhora da Luz da Mata & - & 320 \\
\hline Maranguape & 70 & 100 \\
\hline Olinda & - & 660 \\
\hline São Pedro Mártir & - & 200 \\
\hline Recife & 2,000 & 2,450 \\
\hline Várzea & 600 & 260 \\
\hline Santo Antônio da Mata (50 km from Recife) & 90 & 150 \\
\hline Muribeca & 400 & 400 \\
\hline Jaboatão & 314 & 350 \\
\hline Cabo de Santo Agostinho & 650 & 700 \\
\hline Ipojuca & 300 & 300 \\
\hline Indian village & 840 & - \\
\hline Serinhaém & 600 & 400 \\
\hline Una & 200 & 200 \\
\hline Indian village & 80 & - \\
\hline São Bento & - & 120 \\
\hline Porto Calvo & 370 & 255 \\
\hline Camaragibe & 230 & 310 \\
\hline Subtotal & 11,154 & 11,485 \\
\hline \multicolumn{3}{|c|}{ Strip II - Alagoas: 150 km between Alagoas and Penedo } \\
\hline Lagoa do Norte & 212 & 200 \\
\hline Lagoa do Sul & 307 & 540 \\
\hline São Miguel & 150 & 180 \\
\hline Rio de São Francisco/Penedo & 500 & 300 \\
\hline Subtotal & 1,169 & 1,220 \\
\hline
\end{tabular}


Table 4. Continuation

\begin{tabular}{lcc} 
& 1693 & 1701 \\
\hline Strip III - Rio Grande do Norte & - & 120 \\
Goianinha & 300 & 400 \\
Rio Grande do Norte & 200 & - \\
$\quad$ Two villages & 50 & - \\
$\quad$ Two villages & 550 & 520 \\
Subtotal & & 115 \\
Sertão & 280 & 80 \\
Rodelas & - & \\
Ceará & & 160 \\
Rio Grande do Sul & - & - \\
Rio de Piauí & - & 355 \\
Place among Piancó and Piranhas & 280 & 13,580 \\
Subtotal & 13,153 & \\
Total & & \\
\hline
\end{tabular}

Source: Archivium Secretum Vaticanum/Congregazione del Concilio/Relationes diocesium 596 - fólios não numerados. Documents date from July 11, 1693 and from May 7, 1701, respectively; the latter also has an Italian version titled Visita che monsignore D.F. Francesco de Lima, vescovo Olinden[se] Pernambuccano ne/[lo] stato del Brasile in Indiis Occidentalibus fà ad sacra limina apostolorum, e relatione que del d[ett]o suo vescovato da a nostro signore per l'avvocato Manuele Banha Quaresma, chierico e beneficiato eborense suo procuratore.

Notes:1) The number of hearths presented in 1693 for Recife $(10,000)$ is an obvious error, and must refer to the number of inhabitants, which, in this case, is 2,000 hearths (instead of "dieci milla fuochi", "due milla fuochi"); moreover, it does not present figures for the parishes of Sé de Olinda and São Pedro Mártir. This error is also highlighted by Bruno Feitler, Nas malhas da consciência - Igreja e Inquisição no Brasil: Nordeste 1640-1750, São Paulo, Phoebus; Alameda, 2007, p. 47; 2) the parishes mentioned in the documents currently correspond to the following locations: 2.1) the city of Paraiba is currently João Pessoa; 2.2) in the parish of Goiana, the village of the uraitaigi Indians is included without mention to the number off ires, which today corresponds to the municipality of Alhandra; 2.3) Taquara: currently a district of the municipality of Pitimbu (PB); 2.4) Desterro: currently, the municipality of Itambé; 2.5) Tejucopapo: currently a district of the municipality of (PE); 2.6) Maranguape: currently a neighborhood in the city of Paulista (PE); 2.7) Várzea: currently a neighborhood in the city of Recife; 2.8) Nossa Senhora da Luz da Mata, currently a district of Matriz da Luz, in the municipality of São Lourenço da Mata, $15 \mathrm{~km}$ from the center of the eponymous city; 2.9) Muribeca: currently a neighborhood of the city of Jaboatão dos Guararapes; 2.10) in the document from 1693, the village of Araribá is named as "Ararota"; corresponds today to the municipality of Pesqueira (PE), at a distance of $200 \mathrm{~km}$ from Recife; 2.11) Una: according to José Cezar de Menezes (Idéa da população da capitania de Pernambuco: e das suas annexas ... desada o anno de 1774 em que tomou posse do governo das mesmas capitania, Rio de Janeiro: Officinas Graphicas da Bibliotheca Nacional, 1924, p. 48-49), "the mother church of Nossa Senhora da Purificação [patron saint named in 1693] and São Gonçalo [patron saint named in 1701]... and its population is situated in a mount they call São Gonçalo, neighboring the river of Una"; was situated on the left bank of the river and is now part of the city of Barreiros (PE); 2.12) Camaragibe: not to be confused with the eponymous municipality near Recife; 2.13) "Lagoa" in the document from 1693; "Alagoa" in the one from 1701. Alagoa do Norte: currently Maceió; Alagoa do Sul: currently a municipality of Marechal Floriano, both situated in Alagoas; the parish of Alagoa do Sul includes an Indian village with no indication to the number of hearths; 2.14) São Miguel: currently a municipality of São Miguel dos Campos (AL); 2.15) Rio de Piauí: parish of Nossa Senhora da Vitória, currently the municipality of Oeiras (PI); 3) "Rio de São Francisco" in the document from 1693; "Penedo", in the one from 1701; includes four Indian villages with no indication of the number of hearths; 4) the three last parishes in the table were instituted in the hinterlands because "multitudes of Christians living in the dilated hinterlands in many and large cattle corrals, which are the most profitable farms, to which, every year, crowds of men are going from the Kingdom of Portugal, where they do not have a good life, and in which they spent 8 to 10 years since they last attended a Mass or received the sacraments"; 5) Rio Grande do Sul: previously São Francisco das Chagas do Rio Grande do Sul, currently a municipality of Barra, in Bahia; the document from 1701 informs: "in these distant hinterlands if the aforesaid parish of Conceição da Rodela, 120 leagues farther into the woods to the west, a parish was established [...] with 130 residents in many other cattle corrals"; 6) about Ceará, the document from 1693 states that it was a "a captaincy and a fortress with a military prison, 600 miles distant from the city [Olinda]; the priests of the congregation of São Filipe Neri attend the parish [church], one of whom is responsible for the care of the souls, which are [in number] ... ", without mentioning the figure; the document from 1701 ("Ceará Grande") indicates that the mother church of Nossa Senhora da Assunção had 80 hearths of white residents and a significant number of Indians; coincides with the current municipality of Ceará; 7) the document from 1701 mentions the "place between Pinhanco [currently Piancó] and Piranhas", "150 leagues distant from the mother church of Paraíba, into the hinterlands", which is almost 1,000 km. However, the distance from São José de Piranhas and Piancó to João Pessoa does not exceed 500 km; 8) about Rio Grande do Norte, the document from 1701 states that: "desert scrublands inhabited by some white residents, who live on livestock, and innumerable heathens, some of them tamed, in missions, and mostly barbarians, who engage in their continual wars with whites". 
Regarding the State of Maranhão and Grão-Pará, the data collected and systematized by Rafael Chambouleyron, from a much more diverse although very divergent set of sources, clearly point to a demographic growth in the second half of the 17th century (Table 5). The author also noted an increased inflow of Africans in the final decades of the 17 th century. ${ }^{34}$ If one applies the principle that "neighbor", "resident", or "couple" means "hearth" to the table that summarizes the data collected by him, then we would observe the entire state of Maranhão and Grão-Pará had a population of Portuguese origin not

Table 5. Population of the State of Maranhão and Grão-Pará, 1637-1698

\begin{tabular}{lcccccccc} 
& 1637 & 1660 & 1662 & 1679 & 1684 & 1685 & 1693 \\
\hline Maranhão & & & & & & & \\
São Luís & 250 & $300-500$ & $>600$ & 400 & 800 & $>1,000$ & $>600$ \\
\hline Tapuitapera & - & 100 & - & 30 & - & 400 & 300 \\
\hline Itapecuru & - & - & 100 & 300 & - & - & - \\
\hline Pará & & & & & & & \\
\hline Belém & 80 & 150 & 400 & - & 150 & 500 & 400 \\
\hline Gurupá & - & 30 & - & - & - & - & - \\
Vigia & - & - & - & 22 & - & - & - \\
Caeté/Gurupi & - & 60 & 120 & 18 & - & - & - \\
\hline Totais & 330 & 340 & 1,220 & 770 & 950 & 1,900 & 1,300
\end{tabular}

Sources: Rafael Chambouleyron, Portuguese colonization of the Amazon region, 1640-1706, Tese de doutorado, University of Cambridge, Cambridge, 2005, p. 65-68; Rafael Chambouleyron, "Escravos do Atlântico equatorial: tráfico negreiro para o Estado do Maranhão e Pará (século XVII e início do século XVIII)", Revista Brasileira de História, vol. 26, n. 52, 2006, p. 79-114. The referred sources are the following: for 1637: Bento Maciel Parente, "Relação do Estado do Maranhão: 4 de fevereiro de 1637", Anais da Biblioteca Nacional, vol. 26, 1904 (1905), p. 353-359 (total of "residents"); for the decade of 1660: Notícia do Estado... Biblioteca da Ajuda, códice 50-V-37, fl. 139-139v (total of "neighbors"; Cametá with "few"); for 1662: Maurício de Heriarte, "Descrição do Estado do Maranhão, Pará, Curupá e rio das Amazonas", In: Francisco Adolfo de Varnhagen, História Geral do Brasil, vol. 3, São Paulo, Melhoramentos, 1956, p. 211; 213; 217; $219 ; 221$ (total of "residents" in São Luís and Curupi; for Belém, "neighbor residents"; Gurupá with "some" and Cametá with "few White residents"); for 1679: Simão e Sousa, Sobre o Maranhão e Pará e desordens dos ministros e oficiais que lá há, Biblioteca da Ajuda, Lisboa, 21 de outubro de 1679, códice 50-V-37, fls. 398-405, fl. 398 (total in "couples"); for 1684: João de Moura, a Portuguese colony that has three treaties: in the first, the State of Maranhão and its expansion has been described, 1684, Biblioteca Nacional de Portugal, Reservados, códice 585, fl. 13v (total of "neighbors" in São Luís and of "hearths" in Belém); for 1685: Manuel Guedes Aranha, "Papel político sobre o Estado do Maranhão" [c.1685], Revista do Instituto Histórico e Geográfico Brasileiro, 1a parte, tomo 46 (1883), p. 4; 7; 12 (total of "neighbors" in São Luís and of "residents" in Belém); for 1693: João de Souza Ferreira, "América abreviada, suas notícias e de seus naturais, e em particular do Maranhão, títulos, contendas e instruções à sua conservação e aumento mui úteis" [1693], Revista do Instituto Histórico e Geográfico Brasileiro, 1a parte, tomo 57 (1894), p. 33; 37; 43 (total of "neighbors" for São Luís and Alcântara and of "residents" for Belém). In addition to these, there are two conflicting estimates for the population of the State of Maranhão in 1688: one of 5,000 or 6,000 "residents", and another of 2,000 "residents": Papel sobre ... Sociedade de Geografia e Lisboa, Res. 2-B-6; and João de Sousa Ferreira, "Noticiário Maranhense" [1688?], Revista do Instituto Histórico e Geográfico Brasileiro, vol. 81, 1917, p. 289-352; 344.

Notes: 1) The source from 1637 further adds to the total of residents 60 soldiers living in São Luís, 50 in Belém, 30 soldiers at the fort in Ceará (where four or five residents would also live) and at the fort of Gurupá, less than 30 soldiers with no residents; 2) to the total number of neighbors in São Luís in 1685, a total of 150 soldiers were added, and, in Belém, "200 men who can take up arms".

34Rafael Chambouleyron, "Escravos do Atlântico equatorial: tráfico negreiro para o Estado do Maranhão e Pará (século XVII e início do século XVIII)", Revista Brasileira de História, vol. 26, n. 52, 2006, p. 79-114. 
exceeding 6,000 individuals in the late 1660s and that would have risen in the 1680 s and 1690s to somewhere around 10,000 people. In this area, still according to the author, the number of slaves imported would not exceed 1,500 slaves between the 1670s and the first decade of the 18th century. Undoubtedly, the main issue is having some minimally safe parameter to measure the total number of indigenous population integrated into this set, which was certainly considered in the missionary settlements. ${ }^{35}$

In summary, while the number of Brazilian inhabitants proposed by Rodrigues Contreiras for the 16th century does not differ from that shown by other important authors referred, it changes considerably in the 17th century. As for 1660, the source of the data collected by Rocha Pombo is not given. The same problem occurs regarding the populations in the middle and the late 17th century. Again, the problem is the absence of reliable sources, and the freedom to "venture-to-say" figures, some downright unrealistic, such as 60,000 slaves in São Vicente. No doubt, this is a statistical exercise, largely subjected to all sorts of exceptions, the first of which, the reliability of the sources. But, at least, it allows us to consider, relying on clearer bases, Brazil's population in the period prior to the large demographic movement within the territory, which was caused by mining.

${ }^{35}$ In that regard, refer to the information, although not precise, by Maurício de Heriarte, "Descrição do Estado do Maranhão, Pará, Gurupa e rio das Amazonas", In: Francisco Adolfo de Varnhagen, História Geral do Brasil, vol. 3, São Paulo, Melhoramentos, 1956, p. 189-190. 